\title{
Rethinking Rural and Agricultural Development Through Market-Oriented Technologies in Africa
}

\author{
Bishop O. Ovwigho ${ }^{1}$ \\ ${ }^{1}$ Department of Agricultural Economics and Extension, Delta State University, Nigeria \\ Correspondence: Bishop O. Ovwigho, Department of Agricultural Economics and Extension, Delta State \\ University, Asaba Campus, Asaba, Delta State, Nigeria. E-mail: bishopvwigho@yahoo.com
}

Received: December 22, 2013 Accepted: January 23, 2014 Online Published: January 25, 2014

doi:10.5539/sar.v3n1p85

URL: http://dx.doi.org/10.5539/sar.v3n1p85

\begin{abstract}
The broad objective of the paper was to design a market oriented technology for agricultural and rural development in Africa. Marketing extension has been over looked in extension services delivery. Many of the agricultural technologies including the Top-Bottom, Feed-back, Farmer-Back to Farmer and Integrated Rural Development lacked in-built marketing components. The technology versus market component model was developed in this study. The model consists of the technical, market, and sustainability components as well as control mechanism. The theory of the technology and marketing component model states that, if the technical, marketing and sustainability components of a technology are properly designed implemented and controlled farmers will derive greater incentives from their investment. The marketing component should be specified in all agricultural technology after verifying the technical and sustainability components. Advisory services on marketing functions, role of cooperatives and organized markets in improving market incentives to the rural small and medium scale farmers were discussed. The model is recommended to research scientists and extension workers to adopt in a bid to improve the welfare of the rural farmers.
\end{abstract}

Keywords: agricultural technology, technology transfer, marketing, rural development, poverty

\section{Introduction}

\subsection{Background of the Study}

Rural development could be viewed as the umbrella name for all development activities in the rural areas of the world. Rural development is any purposefully induced change for better living (Ayanwu, 1992). The nexus of rural development encompass agriculture, human capital development (education), skills acquisition, health and nutrition, poverty alleviation programmes, provision of recreational facilities, cottage industries and rural infrastructure. A measurement upwards of the afore-mentioned aspects of rural development connotes rural development. In rural Africa, the primary goal of rural development is to induce agricultural transformation particularly through the instrument of agricultural extension services and adoption of new technologies by farmers.

Agricultural extension serves as a bridge between the rural farmers and research institutes, universities, ministries of agriculture, development intervention agencies and NGOs. Van den Ban and Hawkins (1996) stated that the goals of agricultural extension included transferring of knowledge from researchers to farmers, advising farmers in their decision making, enabling farmers to clarify their own goals and possibilities, and stimulating desirable agricultural development

Over the years agricultural extension services have been technology or innovation driven with little or no emphasis on marketing agricultural produce. FAO (2013a) stated that as farmers become more market oriented, so extension workers need to be in a position to advise them not only on how to grow crops but also on how to market them. Knowledge of produce handling, storage and packaging was essential to the performance of the farmer in his farming business.

Several models of technology adoption and extension systems have been practiced in African countries yet rural poverty remain a conundrum, a starring debacle and a perpetual aura surrounding rural farm families. The United Nations report (2013) on the achievement of the MDGs posited that more than one billion people still lived in extreme poverty all over the world. Rural areas in sub- Saharan Africa are worst hit in terms of poverty despite 
their esteemed economic importance. Cleaver and Graeme (1995), IFAD (2001) and SESRTCIC (2007) reiterated the fact that larger percentages of the world's poor lived in rural areas. The rural people accounted for almost 75 per cent of world's poor people (Global Monitoring Report, 2013).

There is a strong relationship between agricultural stagnation and poverty in sub-Saharan Africa. Much, though not all, of the solution for poverty alleviation depends on stimulating agricultural growth in Africa. Data collected by the World Bank, the Food and Agricultural Organization of the United Nations (FAO), and the African governments, shows that most of Africa's poor live in rural areas and depend on agriculture for survival. The dependence is both direct in growing food and cash crops, and indirect by working on farms or by trading in agricultural inputs and products (Cleaver \& Graeme, 1995).

Ovwigho and Ifie (2009) defined a rural area as a socio-political entity where the major occupation is farming (crop, fishing and livestock production) and related income generating activities such as processing of agricultural produce, native soap making, weaving, game haunting and pottery. They also mentioned that most rural areas in Africa were characterised by small population size, few or no industries as well as lack of social and basic amenities of life.

\subsection{Problems of Implementing Agricultural Development Programmes}

National governments and international development intervention agencies have implemented variegated rural and agricultural development projects. Notable examples were the green revolution programmes and the World Bank assisted agricultural development projects. These programmes were laudable, feasible and contributed to measurable success in rural and agricultural development. However, many of the programmes appear alienated to the farmers' problems coupled with the rent-seeking behaviours of officials charged with the responsibilities of implementation.

According to Benjaminsen et al. (2013) rent seeking came up in wild life management in Tanzania when central control over wildlife was introduced and wildlife revenues continued to be captured by local, regional and state elites. Following the central control Presidential licences were 'regularly issued to friends of the Minister or Director, or to former holders of these posts and concessions were allegedly leased to smaller national companies silently owned by senior public officials with political links in Ministry or Wildlife Department' (Leader-Williams et al., 2009) Among observers of the wildlife sector in Tanzania, there is general agreement that the hunting business is marked by extensive corruption (Jansen, 2009; Leader-Williams et al., 2009; Nelson, 2009, 2010; Sachedina, 2008).

In Nigeria rent seeking behaviour in the form of corruption has become a national malaise in the management of government sponsored agricultural and rural development programmes and projects. Orubu (2013) attributed the slow pace of economic development in Nigeria to corruption. He defined corruption as an illegal form of rent seeking behaviour. ADB (2001) as cited by Orubu (2013) stated the corruption in Nigeria was not that officials were corrupt but corruption was official.

Though rent-seeking behaviour is major attenuating factor to success of rural and agricultural development much still depends on the sensitivity of the programme to the plight and needs of the intended beneficiaries, There is need to develop programmes or services that are intrinsic to the immediate needs or problems of the rural farm families. Thus this article is designed to present a discussion of previous models of agricultural and rural development with a view to developing an agricultural technology and marketing component model for the purpose of improving the welfare of rural farmers in Africa.

\subsection{Agricultural Extension Models}

Several agricultural extension models and systems geared towards agricultural development have been developed by professionals and experts in the field of agricultural development. It suffices to mention that Ogunfiditimi and Ewuola (1995) described twelve agricultural extension systems. These were the Conventional Ministry Approach, University Organized Type, the Cooperative Extension System, Commodity Focused Approach, the Community Type, Integrated Agricultural Development Approach, Integrated Rural Development, Animation Rurale, Training and Visit System, Farming System Research and Extension, Private Sector Extension Type, and Total Extension System. The Conventional approach, and Training and Visit (T \& V) system of technology transfer were the most popular. Swanson (1997) described the conventional technology transfer model (Figure 1). The model explains the linkages and institutional framework for the transfer of technology to the farmers. The model is used by ministry of agriculture and other government officials in reaching the farmers with new technologies. Anderson and Feder (2003) noted that extension services have good public support and were delivered by civil servants. 


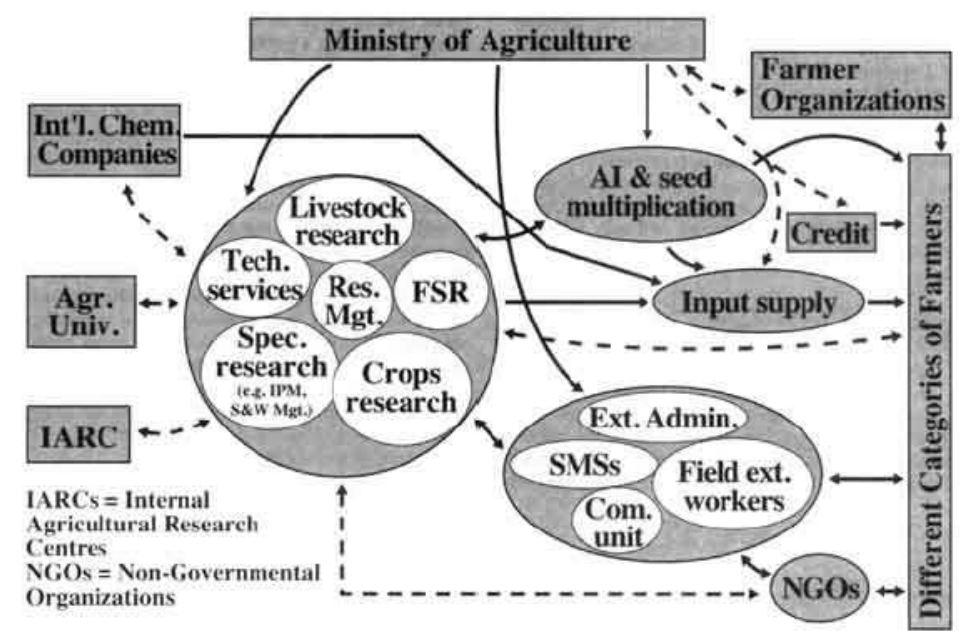

Figure 1. Institutional components of an agricultural technology system

Source: Swanson, 1997. Strengthening research-extension-farmer linkages.

FAO (2013b) stated that the conventional transfer-of-technology was characterised by the top-down and feedback communication models. In the top-down model (Figure 2), technology transfer was a one-way process where technologies developed by scientists were passed on to extension services to be transferred to users. The weakness of this model was that it did not involve farmers in identifying the constraints and adapting the research to local conditions. This model has failed in areas where the farming system is complex.



Figure 2. The top-down technology transfer model

Source: FAO (2013b). Alternative research and extension systems technology transfer models.

The feedback model (Figure 3) was an attempt to overcome the weaknesses of the top-down model. In this model the response of users to the new technology was gathered. However, this feedback was considered to be weak as the users remain passive recipients of technology and the feedback function solely rests with the extension service (Stoop, 1988 as cited by FAO 2013b). 


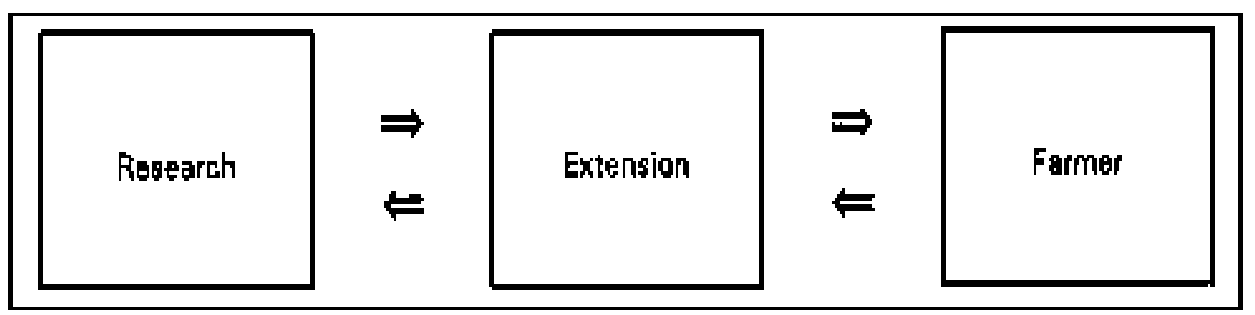

Figure 3. The feedback technology transfer model

Source: FAO (2013b). Alternative research and extension systems technology transfer models.

An improved version of this model is the modified feedback technology model (Figure 4), in which importance was given to identification of farmer target groups in the recommendation domain.



Figure 4. The modified feedback technology transfer model

Source: FAO (2013b). Alternative research and extension systems technology transfer models.

The modified feedback model led to the farmer-back-to-farmer model (Figure 5).

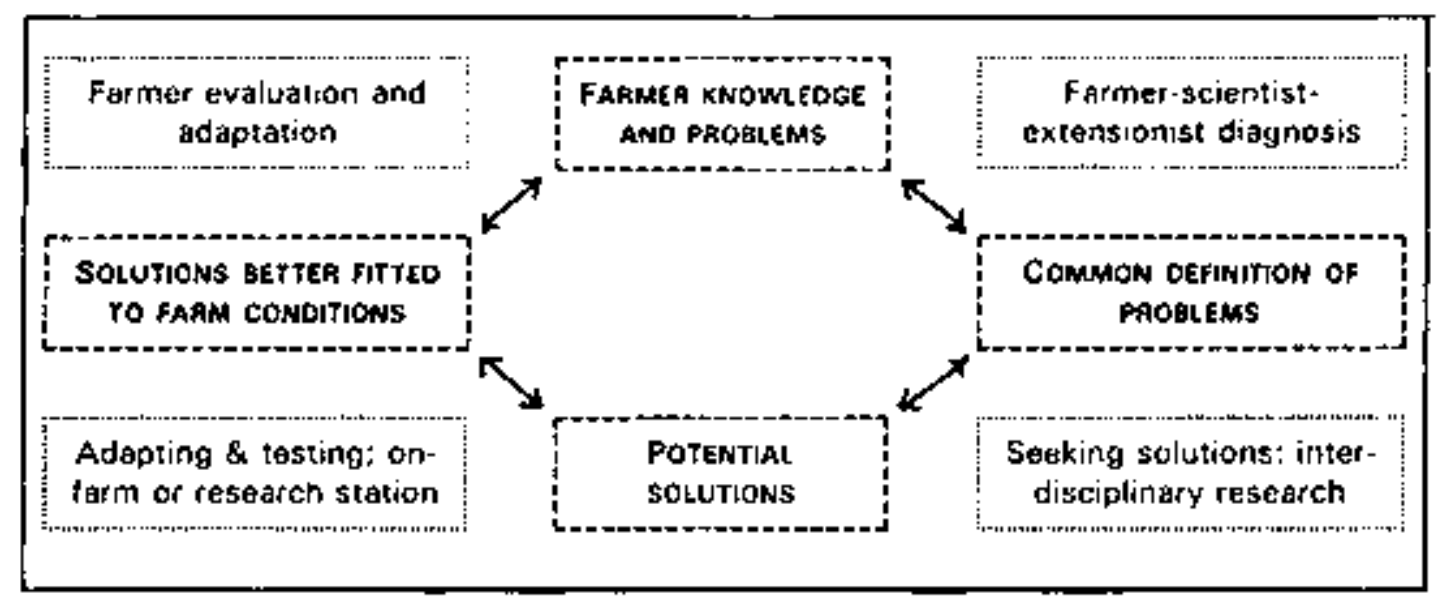

Figure 5. Farmer-back-to-farmer' technology generation and transfer system

Source: FAO (2013b). Alternative research and extension systems technology transfer.

According to Rhoades and Booth (1982) as cited by FAO (2013b) the farmer-back-to-farmer model was designed to improve the two-way communication between the farmer and extension organisations. In this model, farmers and extension personnel were actively involved in the research process. It is based on the assumption that farming systems research/extension research (FSR/E) must begin and end with the farmer. The model involves diagnosis to 
define problems; interdisciplinary team research to develop potential solutions; on-farm and experiment station testing and adaptation of proposed solutions to farmer's conditions, and farmer evaluation and adaptation of the technology and monitoring of its adoption (Stoop, 1988 as cited by FAO, 2013b). The degree of farmer participation and integration between on-station and on-farm research is high in this model compared with the modified feedback model (FAO, 2013b).

Swanson and Rajalahti (2010) maintained that the technology transfer model of extension was prevalent during colonial times and re-emerged with intensity during the 1970s and 1980s when the Training and Visit (T\&V) system was established in many Asian and Sub-Saharan African countries. They admonished that agricultural development goals should go beyond the primary focus on technology transfer in the twentieth century. They maintained that in addition to transferring new technologies in this modern era, priority should be given to increasing farm incomes, maintaining national food security, empowering farmers by building social capital within rural communities, training farmers to use sustainable natural resource management practices and improving rural livelihoods.

The deficiencies of the conventional transfer of technology models have given rise to more clientele involvement approaches including the Participatory Rural Appraisal and Farmer Field School. According to Igbokwe and Enwere (2001) the Participatory Rural Appraisal arose from the inadequacies of the conventional approaches to rural development, agricultural research and extension in Asia, Africa and Latin America. They defined Participatory Rural Appraisal as approaches and methods which enable local people to share, enhance and analyze their knowledge of life and conditions, to plan and act on their own. They further emphasized that the use of PRA enables local people to undertake their own appraisal, analysis and actions as well as monitoring and evaluation of programmes designed for their benefits. The methods of PRA include direct observation, semi structured interviewing, Focus Group Discussion, Matrix scoring and pair wise ranking, diagramming and scoring, community sketch maps, social maps, village transect, farm sketches, seasonal calendar, time trends, time lines, historical profiles, Team contract, flow or linkage diagrams, Venn and network diagrams and workshops/shared presentation (Igbokwe \& Enwere, 2001; Pretty \& Vodouhê, 1997)

The Farmer Field School is a form of adult education, which evolved from the concept that farmers learn optimally from field observation and experimentation. It was developed to help farmers tailor their Integrated Pest Management (IPM) practices to diverse and dynamic ecological conditions. In regular sessions from planting till harvest, groups of neighbouring farmers observe and discuss dynamics of the crop's ecosystem. Simple experimentation helps farmers further improve their understanding of functional relationships (for example pests-natural enemy population dynamics and crop damage-yield relationships). In this cyclical learning process, farmers develop the expertise that enables them to make their own crop management decisions. Special group activities encourage learning from peers, and strengthen communicative skills and group building (Anderson \& Feder, 2003; FAO, 2013c).

\subsection{Models of Rural Development}

Several models of rural development have been practised in developing countries. The most important were the urban, sectoral and integrated rural development models. The urban development model was the earliest development model. The urban development model favours the concentration of development projects in the urban areas. The underlying assumption was that benefits of urban development would trickle down to the rural areas and stimulate rural growth (Rondinelli et al. 1978 as cited by Ayichi, 1995). Experience has shown that the trickle down hypothesis implicit in this model was not always true (Ayichi, 1995). The sectoral development model views agricultural development as the same as rural development. It focuses basically on agricultural development since agriculture is the main stay of most rural areas in Africa. This approach has been found ineffective because rural development embraces all facets of rural life including education, health services, transport, industry, commerce, social welfare and politics (Ayichi, 1995).

The latest approach to rural development has been the integrated rural development. The World Bank and UNDP made use of this approach in several development initiatives in developing countries. The Agricultural Development Projects sponsored by the World Bank is a practical example of the Integrated Rural Development model. The advocates of this approach believe that the problem of rural development was how to eradicate integrated rural poverty which could only be achieved through integrated strategy (Lele \& Adu-Nyako, 1991). The integrated approach sought to develop all sectors of the rural economy and effectively link them to urban economy. It encourages mutually supportive urban and rural linkages. It aims at increasing the contribution of the rural sector to the Gross Domestic Product (GDP) and to enthrone equity in the distribution of gains of increased productivity between the urban and rural dwellers. The strategy entails government and community 
cooperative participation in the provision of better health services, education and rural infrastructure coordinated simultaneously in such a manner as to enhance the overall welfare of the rural dwellers (Ijere, 1992).

\section{Technology and Marketing Component Model}

The main objective of the technology and marketing component model is to enable farmers particularly the rural farm families derive the utmost benefit from their farming endeavour. The theory of the technology and marketing component model states that, if the technical, marketing and sustainability components of a technology are properly designed implemented and controlled farmers will derive greater incentives from their investment (see Figure 6).

\begin{tabular}{|c|c|c|c|c|c|c|c|c|}
\hline SOURCES & $\begin{array}{l}1 \\
1 \\
1\end{array}$ & COMPONENTS & $\begin{array}{l}1 \\
1 \\
1\end{array}$ & BENEFICIARIES & $\begin{array}{l}1 \\
1 \\
1 \\
1\end{array}$ & CONTROL & $\begin{array}{l}1 \\
1 \\
1 \\
1\end{array}$ & \multirow[t]{2}{*}{ RESULTS } \\
\hline & 1 & & 1 & & 1 & & 1 & \\
\hline - Universities & 1 & Technical & 1 & & 1 & & 1 & \\
\hline - Research & 1 & - Durability & 1 & & 1 & & 1 & \\
\hline Institutes & 1 & - Feasibility & 1 & & 1 & & 1 & \\
\hline - NGO's & 1 & - Parts & I & & 1 & & 1 & \\
\hline - Ministries & 1 & ---------- & i & & i & & 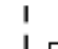 & \\
\hline & $i$ & Marketing & 1 & & i & & 1 & \\
\hline & 1 & - Costs of & 1 & & 1 & & 1 & Improved SES \\
\hline by & $\begin{array}{l}1 \\
1\end{array}$ & $\begin{array}{ll}\text { production } \\
\text { - } & \text { Profitability }\end{array}$ & 1 & & I & - Avoid rent seeking & $\begin{array}{l}1 \\
1 \\
1\end{array}$ & $>$ Increase \\
\hline Innovations T & 1 & - Grading & & - Farmers & 1 & - Proper monitoring & $i$ & Increased use \\
\hline echnologies & $\Leftrightarrow$ & - Available market & $\stackrel{1}{\longrightarrow}$ & - Farmer's & $\underset{1}{\longrightarrow}$ & and evaluation & $\Leftrightarrow$ & of inputs \\
\hline & $i$ & - Price information & 1 & organization & 1 & - Credit support & {$\left[\begin{array}{l}1 \\
1 \\
1\end{array}\right]$} & $>$ Improved \\
\hline & 1 & - Transportation & 1 & & I & - Efficient & 1 & 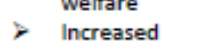 \\
\hline & 1 & - Packaging & 1 & & I & management and & 1 & output \\
\hline & 1 & - Resources use & $\mathrm{I}$ & & I & administration & 1 & \\
\hline & 1 & efficiency & $\mathrm{I}$ & & I & & 1 & \\
\hline & 1 & - Planning and & 1 & & I & & 1 & \\
\hline & 1 & promotion & 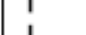 & & I & & 1 & \\
\hline & 1 & - Sales timing & 1 & & I & & 1 & \\
\hline & 1 & - Storage & 1 & & I & & 1 & \\
\hline & 1 & - Type of market & 1 & & I & & 1 & \\
\hline & 1 & Iype or maket & 1 & & I & & 1 & \\
\hline & 1 & Sustainability & 1 & & $\mathrm{I}$ & & 1 & \\
\hline & i & - Ecological & 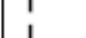 & & I & & 1 & \\
\hline & 1 & - Economic & i & & i & & 1 & \\
\hline & 1 & viability & 1 & & $i$ & & 1 & \\
\hline & 1 & - Socio-cyltural & 1 & & 1 & & i & \\
\hline & 1 & - Trialabilitr & $\mathrm{I}$ & & I & & 1 & \\
\hline & 1 & - Tnalability & 1 & & $\mathrm{I}$ & & 1 & \\
\hline & 1 & & I & & I & & 1 & \\
\hline & 1 & & 1 & & 1 & & 1 & \\
\hline
\end{tabular}

Figure 6. Technology and market component model

Any agricultural technology should consist of technical, marketing and sustainability components. The technical components include technical feasibility, durability, applicability and availability of parts. The marketing components of agricultural technology encompass among others the availability of markets, price information of inputs and outputs, costs of production, profitability, grading, transportation, packaging, resource use efficiency, planning and market promotion, sales timing, storage and types of markets. This agreed with Mohammed et al. (2013), and Adegeye and Dittoh (1982) that agricultural marketing could be compartmentalised as the stages of operations which aid the movement of agricultural commodities from the farms to the consumers. The stages included assemblage of goods, storage, transportation, processing, grading and financing of these activities. The type of markets and marketing functions of the new technology must be specified in the package for improved marketing methods and strategies.

The sustainability component engenders the appropriateness of the innovation. These include ecological compatibility, economic viability, socio-cultural compatibility and trialability potentials. Sustainable development has been defined in many ways, but the most frequently quoted definition is from our common future, also known as the Brundtland Report (1987). This report defined sustainable development as development that meets 
the needs of the present without compromising the ability of future generations to meet their own needs (International Institute for Sustainable Development (2013). Wikipedia (2013) stated that ecologically sustainable development was the environmental component of sustainable development. It could be achieved partially through the use of the precautionary principle if there were threats of serious or irreversible environmental damage. Lack of full scientific certainty should not be used as a reason for postponing measures to prevent environmental degradation. The present generation should ensure that the health, diversity and productivity of the environment was maintained or enhanced for the benefit of future generations. Environmental factors should be more heavily weighted in the valuation of assets and services to provide more incentives for the conservation of biological diversity and ecological integrity (Wikipedia, 2013). Most essentially the new technology should not deplete the environment, for example, the use of chemicals like Lindane which destroys mature and immature fishes in artisanal fishing.

Most adoption researchers agree that the key characteristics which affect adoption of innovations were relative advantage and trialability. Relative advantage could be defined as the degree to which the innovation was perceived as being superior to the former one. Trialability is the ability to try the innovation on a small scale Rogers (2003), Pannell et al. (2006) and Ghane et al. (2011) found that relative advantage, observability, compatibility, trialability, simplicity and social influence were positively related to adoption of Integrated Pest Management practices by paddy farmers in Iran.

A control mechanism is built into the implementation process to guarantee successful outcomes. The expected benefits of the model are improved social economic status, increased income, increased use of inputs, improved welfare and increased output. Om the whole the model suggests the exigencies for research scientists to incorporate marketing component in the development and design of agricultural technologies to enable farmers' desire and adopt new technologies. Swanson (1997) defined technology as the application of knowledge for practical purposes. Generally, technology was used to improve the human condition, the natural environment, or to carry out other socioeconomic activities. He further maintained that technology could be classified into two major categories: (1) material technology, where knowledge is embodied into a technological product such as tools, equipment, agrochemicals, improved plant varieties or hybrids, improved breeds of animals (for example, semen from progeny-tested sires used for artificial insemination), and vaccines; and (2) knowledge-based technology such as the technical knowledge, management skills, and other processes that farmers need to successfully grow a crop or produce animal products (Swanson, 1997)

\subsection{Application of the Technology Market Component Model}

The technology marketing component model could be applied to transfer of technology in virtually all aspects of agriculture (Figure 6). For example in modern snail production, the system of marketing can be included as part of the technology transfer after verifying the sustainability and technical feasibilities. The systems of marketing include storage methods, packaging, grading, price information and markets. The farmers should be educated on where best to sell snails (for example hotels and restaurants) in order to maximise profit.

In crop production, the system of marketing should be specified on improved crop varieties by the technology provider. The farmers should have an initial idea about the economics of the new variety before going into production. The marketing instructions, toxicity level and technical application should be written on the containers of agro-chemicals by manufacturers and institutions. In material technologies like Tractor mounted machines, the marketing components including storage, packaging, cost of production and profit margins should be spelt out by manufacturers or institutions for wholesalers and retailers to see before buying the product.

\subsection{Towards Market Oriented Agricultural Extension Services}

Today, one of the areas of agricultural extension delivery often overlooked is providing marketing extension services by extension agents to farmers. Poverty among rural farmers can be attributed to poor marketing of agricultural produce. The extension workers intermediary role is imperative when the farmer is faced with alternative decisions of where, when and how to sell his products. It is the duty of extension workers to provide advisory services on the marketing functions for various agricultural products (Table 1). 
Table 1. Summary of marketing functions and types of advise for agricultural produce

\begin{tabular}{llll}
\hline S/N & Marketing Functions & Type of advise & Types of Agricultural Product \\
\hline 1 & Available market & Where & All agricultural products \\
2 & Price information & When and where & Crops, livestock, forest products and Fish \\
3 & Transportation & How & Bulky and perishable products \\
4 & Grading & How & Crops, livestock, forest products and Fish, eggs \\
5 & Packaging & How & Eggs, meat, fish \\
6 & Planning and Market promotion & When and where & All agricultural products \\
7 & Sales timing & When & All agricultural products \\
8 & Storage & How and when & All agricultural products \\
\hline
\end{tabular}

The marketing component of agricultural production include available market, grading, price information, transportation, packaging, cost of production, resource use efficiency, profitability, planning and market promotion, sales timing and storage. The type of advise given to the farmer for each marketing function should focus on where, when and how best to market the product.

\subsubsection{Available Market}

For available market the type of advice should be based more on where to sell the product. The extension agent should advise the rural farmer where best to sell for profit maximisation.

\subsubsection{Price Information}

This revolves around advisory services on when and where to sell the product.

\subsubsection{Transportation}

This involves advice on how to transport the product for market efficiency and profitability.

\subsubsection{Grading}

The type of advice should be on how to grade the product for efficiency and attraction.

\subsubsection{Packaging}

The advice under packaging is on how to package for proper transportation and efficiency.

\subsubsection{Planning and Market Promotion}

The type of advice is on when and where to sell for efficiency and profitability.

\subsubsection{Sales Timing}

The advice is on when to sell for more profit.

\subsubsection{Storage}

The type of advice given to the farmer should be on how to store for the purpose of selling when prices are favourable.

Apart from these tit-bits on marketing functions approaches such as formation of cooperatives and organized agricultural produce markets could stimulate market incentives for small and medium scale farmers in rural Africa. Cooperative societies can supply services to the farmers and increase the bargaining power of group members (Akeredolu, 2011). Types of agricultural cooperatives include Farmers' Producer Cooperatives, Farmers' Consumer Cooperatives, Agricultural Produce Marketing Cooperatives, Thrift and Credit Cooperatives, and Multi-purpose Cooperatives (Adegeye \& Dittoh, 1982).

In recent times farmers are being advised by NGOs, development intervention agencies and ministries to form cooperatives in order to be stronger in maximising the gains of agricultural production. The metaphor of most rural farmers in Africa could best be described as 'working from hand to mouth'. The agricultural markets were often unorganized. Farmers in some areas usually display agricultural goods by the road side running from one car to the other or one person to the other in order to sell their goods. Berg and Kent (1991) epitomized this situation when they asserted that an important factor affecting agricultural productivity in Africa was poor market access. They explained that many small scale farmers who rely on agriculture as means of livelihood sell most of their farm produce soon after harvest to either meet immediate cash needs or avoid high grain storage cost. The admonition is that government of African countries should make it a point of duty to build standard markets for agricultural 
produce. The availability of market gives the farmers hope instead of uncertainty that surrounds the marketing of agricultural produce by small and medium scale farmers in Africa.

\section{Conclusion}

Many models of agricultural and rural development have been developed and practiced for the purpose of agricultural and rural development yet poverty remains a major problem among rural farming households. The technology and marketing model developed in this study sought a market component in any new innovation/technology. The model consists of the technical; marketing and sustainability components as well as control mechanism to enable the rural farmers maximize the gains of their agricultural production endeavour. The model can be applied to transfer of technology in any aspect of agriculture. The marketing component should be specified in all agricultural technology after verifying the technical and sustainability components. The model is recommended to research scientists, extension workers and others interested in developing technologies to reduce rural poverty.

\section{References}

Adegeye, A. J., \& Dittoh, J. S. (1982). Essentials of Agricultural Economics. Ibadan: Centre for Agricultural and Rural Development.

Akeredolu, M. (2011). Innovations in the Marketing of Agricultural Produce: The Case of the FASO JIGI Cooperative in Mali. Extension Farming Systems Journal, 7(1), 11-20.

Anderson, J. R., \& Feder, G. (2003). Rural Extension Services. Policy Research Working Paper No. 2976. Washington D. C: World Bank. http://dx.doi.org/10.1596/1813-9450-2976

Ayanwu, C. N. (1992). Community Development: The Nigerian Perspective. Ibadan: Gabesther Educational Books Ltd.

Ayichi, D. (1995). Models of Rural Development in Nigeria. In C. E. Eboh, C. Okoye \& D. Ayichi (Eds.). Rural Development in Nigeria: Concepts, Processes and Prospects (pp. 13-29). Enugu: Auto-century Publishing Company Limited.

Benjaminsen, A., Goldman, M. J., Minwary, M. Y., \& Maganga, F. P. (2013). Wildlife Management in Tanzania: State Control, Rent Seeking and Community Resistance. Development and Change, 44(5), 1087-1109. http://dx.doi.org/10.1111/dech.12055

Berg, E., \& Kent, L. (1991). The Economics of Cereal Banks in the Sahel. Consultancy Report Prepared for USAID. Bethesda, Maryland, USA: Development Alternative Inc.

Cleaver, K. M., \& Graeme, D. W. (1995). Agriculture, Poverty, and Policy Reform in sub-Saharan Africa. World Bank Discussion Papers; No. 280. Washington, D.C: The World Bank. http://dx.doi.org/10.1596/0-8213-3189-2

Food and Agriculture Organization, Food and Agriculture Organization, FAO. (2013a). Marketing Extension. Retrieved from http://www.fao.org/ag/ags/agricultural-marketing linkages/marketing extension/en/

Food and Agriculture Organization, FAO. (2013b). Alternative research and extension systems technology transfer models. Retrieved from http://www.fao.org/docrep/W7508E/w7508e0d.htm

Food and Agriculture Organization, FAO. (2013c). IPM Farmer Field Schools. Retrieved from http://www.fao.org/docrep/006/ad487e/ad487e02.htm

Ghane, F., Samah, B. A., Ahmad, A., \& Idris, K. (2011). The Role of Social Influence and Innovation Characteristics in the Adoption of Integrated Pest Management (IPM) Practices by Paddy Farmers in Iran. Proceedings of the International Conference on Social Science and Humanity, 5, 217-220

Global Monitoring Report. (2013). Rural-Urban Dynamics and the Millennium Development Goals. Retrieved from http://go.worldbank.org/60UGFNSOD0

Igbokwe, E. M. And Enwere, N. J. (2001). Participatory Rural Appraisal in Development Research. Enugu: New Generation Books

Ijere, M. O. (1992). Leading Issues in Rural Development. Enugu: Acena Pblishers.

International Fund for Agricultural Development, IFAD. (2001). The Challenge of Ending Rural Poverty, Rural Poverty Report 2001 IFAD.

International Institute for Sustainable Development. (2013). What is Sustainable Development. Canada: International institute for sustainable development Retrieved from http://www.iisd.org/sd/ 
Jansen, E. G. (2009). Does Aid Work? Reflections on a Natural Resources Programme in Tanzania. U4 Brief No 2. Bergen: Christian Michelsen Institute.

Leader-Williams, N., Baldus, R. D., \& Smith, R. J. (2009). The Influence of Corruption on the Conduct of Recreational Hunting, In B. Dickson, J. Hutton \& W. M. Adams (Eds.), Recreational Hunting, Conservation and Rural Livelihoods: Science and Practice, (pp. 296-316). Oxford: Blackwell. http://dx.doi.org/10.1002/9781444303179.ch18

Lele, O., \& Adu-Nyako, K. (1991). Integrated Strategy Approach for Poverty Alleviation: A Paramount Priority for Africa. African Development Review, 3(1), 1-29. http://dx.doi.org/10.1111/j.1467-8268.1991.tb00035.x

Mohammed, A. B., Mohammed, S. A., Ayanlere, A. F., \& Afolabi, O. K. (2013). Evaluation of Poultry Egg Marketing in Kuje AreaCouncil Municipality of F.C.T Abuja, Nigeria. Greener Journal of Agricultural Sciences, 3(1), 068-072.

Nelson, F. (2009). Reforming Wildlife Governance in East and Southern Africa: The Role of Corruption. U4 Brief No 12. Bergen: Christian Michelsen Institute.

Nelson, F. (ed.) (2010). Community Rights, Conservation \& Contested Land. The Politics of Natural Resource Governance in Africa. London: Earthscan.

Ogunfiditimi, T. G., \& Ewuola, S. O. (1995). The Synthesis of Comparative of Agricultural Extension Systems. Ibadan: Emmi Press Ltd.

Orubu, C. O. (2013). Rent Seeking Behaviour and the Development ProcessP A Sceptical Reflection on the Possibility of a Corruption Kuznets Curve. 32nd Inaugural Lectures of the Delta State University, Abraka Nigeria.

Ovwigho, B. O., \& Ifie, P. A. (2009). Principles of Youth Development in Africa. Benin-City: Ethiope Publishers.

Pannell, D., Marshall, G., Barr, N., Curtis, A., Vanclay, F., \& Wilkinson, R. L. (2006). Understanding and promoting adoption of conservative practices by rural landholders. Australian Journal of Experimental Agriculture, 6(11), 1407-1424. http://dx.doi.org/10.1071/EA05037

Pretty, J. N., \& Vodouhê, S. D. (1997). Using Rapid or Participatory Rural Appraisal. In B. E. Swanson, R. P. Bentz \& A. J. Sofranko (Eds.). Improving Agricultural Extension: A Reference Manual (pp. 67-80). Rome: FAO.

Rogers, E. M. (2003). Diffusion of Innovations, Simon and Schuster, New York.

Sachedina, H. T. (2008). Wildlife is Our Oil: Conservation, Livelihoods and NGOs in the Tarangire Ecosystem, Tanzania. DPhil thesis, School of Geography and the Environment, University of Oxford.

Statistical Economic and Social Research and Training Centre for Islamic Countries, SESRTCIC. (2007). Poverty in Sub-Saharan Africa: The Situation in OIC member Countries. Retrieved from http://www.sesrtcic.org

Swanson, B. E. (1997). Strengthening research-extension-farmer linkages. In B. E. Swanson, R. P. Bentz \& A. J. Sofranko (Eds.). Improving Agricultural Extension: A Reference Manual (pp. 238-245). Rome: FAO.

Swanson, B. E., \& Rajalahti, R. (2010). Strengthening Agricultural Extension and Advisory Services: Procedures for Assessing, Transforming and Evaluating Extension Systems. Agriculture and Rural Development Discussion Paper No. 44. Washington D. C: The World Bank.

United Nations, UN. (2013). Secretary-General's remarks at Special Event on Achieving the Millennium Development Goals. New York.

Van den Ban, A, W., \& Hawkins, H. S. (1996). Agricultural Extension. London: Blackwell Science: California.

Wikipedia. (2013). Ecologically Sustainable Development. Retrieved from en.wikipedia.org/wiki/Ecologically_Sustainable_Development

\section{Copyrights}

Copyright for this article is retained by the author(s), with first publication rights granted to the journal.

This is an open-access article distributed under the terms and conditions of the Creative Commons Attribution license (http://creativecommons.org/licenses/by/3.0/). 